\title{
ANALYSIS OF LEADERSHIP STYLE IN PENGADILAN NEGERI SITUBONDO
}

\author{
Dany Dhiman Septyawan \\ Department of Management FEB UMM \\ E-mail: Danydhiman@gmail.com
}

\begin{abstract}
The purpose of this study is to describe the subordinate maturity, the leadership style of task behavior and relationship behavior and, Analyze the leadership style according to the theory of Hersey and Blanchard. Analyzer used in this research is by using scale analysis. it can be concluded that the level of maturity subordinate in Pengadilan Negeri Situbondo can be described that for the civil service in the category of high, common parts are very high and tge financial section included in the high criteria. Leadership style task behavior on the part of personel, general and financial sections include in the high criteria. Behavior on the part of employment relationship in the category of very high while for the public and included in the criteria of high finance. Leadership style according to the theory of Hersey and Blanchard in Pengadilan Negeri Situbondo is consultative.The suggestion in this research that the leadership should be more active in controlling the activities undertaken bye the employees to provide input and direction so that employees can carry out operational activities of the agency in accordance with the conditions set. Leaders must set a deadline for the finalization of the work so that the work can be completed on time so that the direction given is actually run in line with expectations and leadership should provide encouragement or motivation to employees in order to complete the work that is the responsibility in accordance with the provisions set.
\end{abstract}

Keyword: Leaderhip Style, Behavior Relationship, Task Behavior, Hersey and Blankhard Theory.

\section{PENDAHULUAN}

Kepemimpinan dalam suatu perusahaan merupakan suatu faktor yang menentukan berhasil atau tidaknya organisasi dalam mencapai tujuan-tujuannya. Faktor ini berfungsi sebagai pendorong dalam rangka untuk peningkatan kinerja para karyawan dalam rangka mewujudkan tujuan organisasi. Kemampuan seorang pimpinan untuk memberikan dukungan terkait dalam upaya peningkatan kinerja karyawan sangat diperlukan. Pemimpin dapat pula berperan sebagai pendorong yang harus mempunyai kemampuan memahami orang lain, bisa menghargai anak buahnya dan punya integritas yang tinggi. Kenyataan ini memberikan bukti bahwa adanya keterkaitan antara gaya kepemimpinan dengan pencapaian kinerja karyawan. 
Salah satu bentuk gaya kepemimpinan yang dapat diterapkan oleh seorang pimpinan adalah gaya kepemimpinan situasional. Gaya kepemimpinan situasional dapat mengidentifikasi level tingkat kematangan individu atau kelompok yang hendak dipengaruhi untuk selanjutnya dapat ditentukan gaya kepemimpinan yang sesuai.

Kepemimpinan situasional adalah teori kepemimpinan yang dikembangkan oleh Paul Hersey dan Ken Blanchard yang mengatakan bahwa seseorang pemimpin harus menyesuaikan

gaya

kepemimpinannya (leadership style) dengan tahap pengembangan para bawahannya (follower development level) yakni berdasarkan sejauh mana kesiapan dari para bawahan tersebut untuk melaksanakan suatu tugas yang akan mencakup di dalamnya kebutuhan akan kompetensi dan motivasi. Dasar dari teori kepemimpinan situasional adalah tidak ada satu gaya kepemimpinan yang terbaik, dimana model ini terletak pada dua konsep dasar yaitu perpaduan antara gaya kepemimpinan dan tahap pengembangan/tingkat kematangan karyawan.

\section{Dalam}

kepemimpinan situasional terbagi menjadi empat kriteria gaya kepemimpinan yaitu gaya kepemimpinan telling/directing, dimana situasi ini terjadi pada saat bawahan tidak mampu menjalankan tugas dan tidak mau atau takut mencoba sesuatu yang baru sehingga harus menjalankan peran mengarahkan yang sangat besar dan memerintahkan apa yang harus dilakukan para bawahan. Gaya kepemimpinan ini lebih mengutamakan kemampuan pimpinan dalam rangka untuk menggerakkan para karyawan sehingga selalu mengikuti segala bentuk pentunjuk dalam proses penyelesaian pekerjaan.

Gaya kepemimpinan selling/coaching, dapat memberikan gambaran mengenai situasi yang terjadi pada saat bawahan memiliki kompetensi yang kurang namun mereka memiliki keinginan untuk bekerja yang kuat dan mau mencoba hal-hal yang baru. Selanjutnya situasi kepemimpinan participating/ supporting, menunjukkan dimana pada situasi ini, bawahan memiliki kompetensi yang tinggi tetapi mereka enggan atau memiliki perasaan tidak aman untuk melakukan pekerjaan tersebut.

Adapun yang terakhir yaitu mengenai situasi kepemimpinan delegating/observing, dimana situasi ini karyawan memiliki kompetensi dan juga komitmen yang tinggi untuk menyelesaikan tugas sehingga pemimpin dapat melakukan pendelegasian pekerjaan kepada para bawahan.

Pengadilan Negeri Situbondo merupakan lingkungan Peradilan Umum/Agama dibawah Mahkamah Agung Republik Indonesia sebagai pelaksana kekuasaan kehakiman yang memiliki kebebasan untuk menyelenggarakan peradilan guna menegakkan hukum dan keadilan. Pengadilan Negeri Situbondo merupakan instansi yang memberikan suatu bentuk tanggung jawab dari Mahkamah Agung Republik Indonesia yang bertugas dan berwenang menerima, memeriksa, memutus dan menyelesaikan perkara yang masuk di tingkat pertama. Sebagian instansi pemerintah yang 
memberikan pelayanan kepada masyarakat terkait dengan masalah hukum maka kualitas sumber daya manusia yang dimiliki secara langsung memberikan jaminan atas kualitas pelayanan masyarakat yang diberikan.

Pengadilan Negeri Situbondo merupakan instansi yang memberikan pelayanan kepada masyarakat mengenai masalah hukum, yang dalam aktivitasnya terbagi menjadi beberapa bagian tugas atau pekerjaan yang memiliki fungsi dan peranan yang saling mendukung. Jadi seluruh aktivitas pegawai dibawah kendali oleh seorang pimpinan sehingga proses koordinasi dapat berjalan sesuai dengan ketentuan. Pimpinan selalu berupaya untuk menggerakkan para pegawai untuk bekerja secara maksimal sehingga kinerja para pegawai dapat sesuai dengan harapan instansi melalui upaya untuk menciptakan semangat dalam bekerja diinstansi.

Beberapa kajian hasil penelitian terdahulu yang digunakan dalam penelitian ini yaitu M. Ali Iqbal (2010) Analisis Gaya Kepemimpinan Pathgoal Terhadap Efektivitas Organisasi Pada Badan Penelitian Dan Pengembangan Pertanian, Departemen Pertanian. Hasil analisis dapat diketahui bahwa terdapat pengaruh positif antara kepemimpinan dan efektivitas organisasi dan setelah melalui uji statistik pengaruh tersebut signifikan. Hal ini menunjukkan bahwa kepemimpinan para pejabat di Badan Penelitian dan Pengembangan Pertanian secara signifikan memiliki pengaruh positif terhadap efektivitas organisasi (Ana Elok Imtihanah, 2009), dengan judul penelitian Analisis Gaya Kepemimpinan Dalam Meningkatkan Kinerja Pegawai Pada Fakultas Ekonomi Universitas Islam Negeri Maulana Malik Ibrahim Malang. Hasil penelitian, menunjukkan bahwa Gaya kepemimpinan di Fakultas Ekonomi Universitas Islam Negeri Maulana Malik Ibahim Malang adalah gaya kepemimpinan selling karena dalam fakultas ekonomi tugasnya sangat tinggi dan hubungannya juga sangat tinggi dan piminan selalu memberi pengarahan dan menjelaskan hasil keputusan. Dan juga gaya kepemimpinan di fakultas ekonomi sangat sesuai dengan konsep islam karena kepemimpinannya mengedepankan hubungan yang baik dan keteladanan yang tinggi dan tugas yang sangat maksimal dan optimal.

\section{TINJAUAN PUSTAKA}

Menurut Thoha (2004:256) berpendapat bahwa kepemimpinan adalah kemampuan untuk membangkitkan semangat orang lain dan memiliki semangat total terhadap usaha mencapai tujuan organisasi. Menurut Mohyi (2005:161) yang dimaksud kepemimpinan adalah kegiatan mempengaruhi, mengorganisir, menggerakkan, mengarahkan atau mempengaruhi orang lain (bawahan) untuk melaksanakan sesuatu dalam rangka mencapai tujuan. Kemampuan mengendalikan sumber daya manusia dan dana serta faktor lain untuk mencapai tujuan organisasi merupakan usaha yang harus dilakukan dalam setiap organisasi.

Menurut Arifin Dkk (2005:125) fungsi tersebut adalah merupakan fungsi yang harus 
dilaksanakan atau merupakan beban dan pemimpin. Keberhasilan untuk mencapai tujuan organisasi adalah merupakan kewajiban yang harus dilaksanakan oleh setiap pemimpin.

Gaya

kepemimpinan

merupakan norma yang digunakan sewaktu mencoba mempengaruhi perilaku orang lain. Menurut Thoha (2004:313) pada hakekatnya perilaku dasar pemimpin yang mendapat tanggapan para pengikutnya, sewaktu pemimpin tersebut melakukan proses pemecahan masalah dan pembuatan keputusan, maka empat gaya kepemimpinan dasar situasional dapat diaplikasikan dengan suatu proses pengambilan keputusan tersebut. Gaya kepemimpinan dalam pembuatan keputusan disajikan pada Gambar 1.

\begin{tabular}{|c|c|}
\hline $\begin{array}{c}\text { Partisipasi } \\
\text { (G3) }\end{array}$ & $\begin{array}{c}\text { Konsultasi } \\
(\mathrm{G} 2)\end{array}$ \\
\hline Delegasi (G4) & Instruksi (G1) \\
\hline
\end{tabular}

Sumber : Thoha (2004:314)

Gambar 1. Empat Gaya

Kepemimpinan Dalam Pengambilan Keputusan

\footnotetext{
Perilaku pemimpin yang tinggi pengarahan dan rendah dukungan (G1) dirujuk sebagai instruksi, karena gaya kepemimpinan ini dicirikan dengan komunikasi satu arah. Pemimpin memberikan batasan peranan pengikutnya dan memberi mereka tentang apa, bagaimana, bilamana dan di mana melaksanakan berbagai tugas. Inisiatif pemecahan masalah semata-mata dilakukan oleh pemimpin. Pemecahan masalah dan keputusan diumumkan dan pelaksanaannya diawasi secara ketat oleh pemimpin.

Perilaku pemimpin yang
tinggi pengarahan dan tinggi
}

dukungan (G2) dirujuk sebagai konsulasi, karena dalam menggunakan gaya ini, pemimpin masih banyak memberikan pengarahan dan masih membuat hampir sama dengan keputusan, tetapi hal ini diikuti dengan meningkatkan banyaknya komunikasi dua arah dan perilaku mendukung, dengan berusaha mendengar perasaan pengikut tentang keputusan yang dibuat, serta ide-ide dan saran-saran mereka. Meskipun dukungan ditingkatkan, pengendalian (control) atas pengambilan keputusan tetap pada pemimpin. Perilaku pemimpin yang tinggi dukungan dan rendah pengarahan (G3) dirujuk sebagai partisipasi, karena posisi kontrol atas pemecahan masalah dan pembuatan keputusan dipegang secara bergantian.

Dengan penggunaan gaya kepemimpinan 3 ini, pemimpin dan pengikut saling tukar menukar ide dalam pemecahan masalah dan pembuatan keputusan, komunikasi dua arah ditingkatkan dan peranan pemimpin adalah secara aktif mendengar. Tanggung jawab pemecahan masalah-masalah dan pembuatan keputusan sebagian besar berada pada pihak pengikut. Hal ini sudah sewajarnya karena pengikut memiliki kemampuan untuk melaksanakan tugas.

Perilaku pemimpin yang rendah dukungan dan rendah pengarahan (G4) dirujuk sebagai delegasi, karena pemimpin mendiskusikan masalah bersamasama dengan bawahan, sehingga tercapai kesepakatan mengenai definisi masalah yang kemudian proses pembuatan didelegasikan secara keseluruhan kepada bawahan. 
Bawahan memiliki kontrol untuk memutuskan tentang bagaimana cara pelaksanaan tugas. Pemimpin memberikan kesempatan yang luas bagi bawahan untuk melaksanakan pertunjukkan mereka sendiri karena mereka memiliki kemampuan dan keyakinan untuk memikul tanggung jawab dalam pengarahan perilaku mereka sendiri. Kerangka pikir dalam penelitian ini secara lengkap dapat disajikan pada Gambar 2.

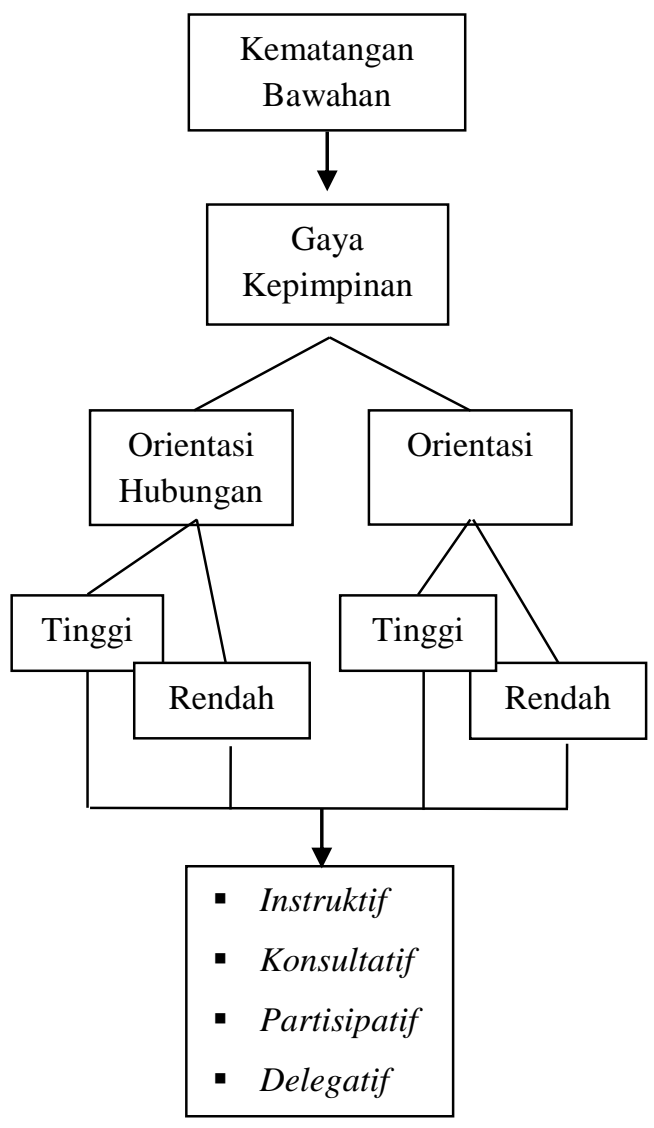

Gambar 2. Kerangka Pikir Penelitian

Berdasarkan kerangka pikir penelitian dapat diketahui gaya kepimpinan pada Pengadilan Negeri Situbondo. Dalam penelitian ini gaya kepemimpinan situasional yang meliputi orientasi tugas dan orientasi hubungan. Orientasi tugas dalam penelitian ini yaitu meliputi instruksi secara jelas, menjelaskan kepada pegawai, memberikan dorongan kepada pegawai untuk memaksimalkan kemampuan, pengendalian atas pekerjaan menetapkan batas waktu. Orientasi hubungan yang meliputi memberikan dorongan, dengan selalu memperhatikan setiap keluhan pegawai, melakukan diskusi tentang pekerjaan yang harus diselesaikan oleh pegawai, mendelegasikan tanggung jawab pengambilan dan berusaha untuk menjaga hubungan baik dengan pegawai.

\section{METODE PENELITIAN}

Lokasi penelitian yang digunakan menjadi objek penelitian ini adalah pada Pengadilan Negeri Situbondo. Jenis penelitian ini adalah penelitian survey dimana peneliti melakukan observasi dalam pengumpulan data, peneliti hanya mencatat data apa adanya, dan menganalisis. Penelitian survey adalah penelitian yang mengambil sampel dari satu populasi dan menggunakan questioner sebagai alat pengumpulan yang cocok.

Populasi yang ditetapkan dalam penelitian ini adalah seluruh pegawai tetap pada Pengadilan Negeri Situbondo yaitu sebanyak 25 pegawai yang terdapat di tiga bagian yaitu meliputi Bagian kepegawaian sebanyak 11 pegawai, Bagian Umum sebanyak 8 pegawai dan Bagian Keuangan yaitu 6 pegawai.

Pengambilan sampel pada penelitian ini dilakukan dengan menggunakan teknik sampling total sampling yaitu teknik penilaian responden yang dilakukan secara 
keseluruhan dengan tanpa memberikan perbedaan apapun, sehingga semua anggota populasi dapat terpilah sebagai sampel (Sugiyono, 2005:65), dengan demikian jumlah sampel penelitian yaitu sebanyak 25 pegawai yang meliputi bagian kepegawaian, bagian umum dan bagian keuangan.

Dalam penelitian ini responden mengunakan 4 kategori, dan tidak menggunakan 5 kategori karena menurut Nazir (2001:39) skala Likert menggunakan item yang secara pasti baik dan secara pasti buruk, tidak dimasukkan yang agak baik, yang kurang buruk, dan yang netral. Teknik analisis data yang digunakan dalam penelitian ini yaitu analisis rentang skala, digunakan untuk mendeskripsikan gaya kepemimpinan orientasi tugas dan orientasi hubungan serta untuk mendeskripsikan kematangan bawahan pada Pengadilan Negeri Situbondo

\section{HASIL PENELITIAN DAN PEMBAHASAN}

Hasil analisis gaya kepemimpinan ketiga bagian pada Pegawai Pengadilan Negeri Situbondo secara sistematis dapat disajikan pada tabel 1 sebagai berikut:

Tabel 1. Hasil Analisis Gaya

Kepemimpinan Pada Pegawai Pengadilan Negeri Situbondo

\begin{tabular}{cccc} 
No & Bagian & $\begin{array}{c}\text { Gaya } \\
\text { Kepemimpinan }\end{array}$ & $\begin{array}{c}\text { Kematangan } \\
\text { Bawahan }\end{array}$ \\
\hline 1 & Kepeg. & Konsultatif & Partisipatif \\
2 & Umum & Konsultatif & Delegatif \\
3 & Keu. & Konsultatif & Partisipatif \\
\hline Sumber:
\end{tabular}

Sumber: Data Diolah

Pada bagian pegawaian hasil analisis rentang skala yang telah dilakukan maka dapat diketahui bahwa gaya kepemimpinan orientasi tugas masuk dalam kriteria tinggi dan orientasi hubungan sangat tinggi. Hasil tersebut menunjukkan bahwa gaya kepemimpinan pada bagian kepegawaian pada Pengadilan Negeri Situbondo yaitu konsultatif, sedangkan apabila ditinjau dari kematangan bawahan maka gaya kepemimpinan yang sesuai yaitu partisipatif.

Mengenai perilaku tugas dapat diketahui bahwa pimpinan menyatakan selalu memberikan instruksi dalam pelaksanaan tugas kepada pegawai. Frekuensi pimpinan dalam memberikan dorongan kerja kepada pegawai untuk proses penyelesaian pekerjaan. Pimpinan selalu memberikan penjelasan secara detail tentang tugas yang harus diselesiakan dan pimpinan selalu mengendalikan pekerjaan secara ketat dalam upaya untuk melaksanakan tugas atau pekerjaan sesuai dengan ketentuan serta menetapkan batas waktu dalam proses penyelesaian pekerjaan.

Selanjutnya mengenai orientasi hubungan menunjukkan bahwa pimpinan menyatakan bahwa selalu menjaga hubungan baik dengan pegawai, dalam memperhatikan keluhan yang disampaikan oleh pegawai, dalam berdiskusi tentang pekerjaan yang harus diselesaikan oleh pegawai, selalu mengkomunikasikan dan mendelegasikan setiap tugas dan tanggung jawab kepada pegawai, dalam berkomunikasi selalu dilakukan dengan baik.

Gaya kepemimpinan yang diterapkan pada bagian kepegawaian dapat diketahui bahwa pimpinan selalu berupaya untuk 
memaksimalkan potensi yang dimiliki para pegawai sehingga pemimpin masih memberi arahan namun pimpinan menggunakan komunikasi dua arah dan memberi dukungan secara emosional terhadap individu atau kelompok guna memotivasi para pegawai untuk bekerja secara maksimal diinstansi. Gaya ini muncul dilakukan oleh pimpinan karena adanya kompetensi para pegawai yang selalu mengalami peningkatan, sehingga pemimpin selalu memberikan bimbingan kepada pegawai sehingga mereka siap untuk melaksanakan pekerjaan yang ditetapkan sesuai dengan beban atau tugas yang telah diberikan oleh instansi.

Adanya perbedaan gaya kepemimpinan tersebut menunjukkan bahwa selama ini pegawai memiliki kemampuan namun demikian mereka ragu untuk menjalankan pekerjaan sesuai dengan ketentuan yang telah ditetapkan. Namun selama ini pemimpin selalu berusaha untuk mengendalikan aktivitas operasional pegawai dengan selalu memberitahu individu atau kelompok soal apa, bagaimana, mengapa, kapan dan dimana sebuah pekerjaan dilaksanakan.

Pemimpin selalu memberikan instruksi yang jelas, arahan yang rinci, serta mengawasi pekerjaan secara langsung, kondisi ini menunjukkan pimpinan berlaku sebagai pengendalian atas aktivitas yang dilakukan pegawai. Perbedaan tersebut dikarenakan selama ini para pegawai sebagian besar memiliki tingkat pendidikan perguruan tinggi atau sarjana dengan masa kerja > dari 4 tahun. Pimpinan selalu berupaya untuk memberikan dukungan yaitu berupa arahan kepada pegawai sehingga dengan kemampuan dan masa kerja yang sekarang mampu melaksanakan tugas kerja sesuai dengan ketentuan.

Terjadinya perbedaan gaya kepemimpinan tersebut dikarenakan selama ini tugas utama dari bagian kepegawaian yaitu terkait secara langsung dengan proses pengelolaan atas keberadaan sumber daya manusia atau pegawai diinstasi. Tugas yang harus dilakukan bagian kepegawaian yaitu mencakup seluruh aktivitas yang dilakukan oleh pegawai yaitu memproses pengusulan kenaikan pangkat, kenaikan jabatan berkala, pensiun, cuti dan usulan mengikuti ujian dinas.

Beberapa tugas yang harus diselesaikan tersebut secara langsung membutuhkan gaya kepemimpinan konsultatif, dimana bagian kepegawaian dalam aktivitasnya mencakup seluruh elemen yang terdapat dalam instansi sehingga membutuhkan arahan dari pimpinan yaitu dengan menggunakan sistem komunikasi dua arah sehingga dapat terbentuk suatu yang dapat meningkatkan motivasi para pegawai dalam bekerja di instansi.

Pada bagian umum dapat diketahui bahwa gaya kepemimpinan orientasi tugas dan orientasi hubungan masuk dalam kriteria tinggi. Hasil tersebut menunjukkan bahwa gaya kepemimpinan pada bagian umum pada Pengadilan Negeri Situbondo yaitu konsultatif. Apabila ditinjau dari kematangan bawahan maka gaya kepemimpinan yang sesuai yaitu delegatif. Hasil tersebut menunjukkan bahwa selama ini pimpinan bagian umum dapat diketahui bahwa pengetahuan yang 
dimiliki pegawai mendukung dalam proses penyelesaian pekerjaan, pegawai memiliki keterampilan dalam menyelesaian pekerjaan yang telah dilakukan, pengalaman kerja yang dimiliki pegawai dalam mendukung kebutuhan kerja, dapat meminimalkan pelanggaran prosedur kerja dan penyelesaian pekerjaan pegawai sesuai dengan target waktu yang telah ditetapkan.

Apabila ditinjau dari perilaku tugas maka dapat diketahui bahwa pimpinan menyatakan selalu memberikan instruksi dalam pelaksanaan tugas kepada pegawai. Frekuensi pimpinan dalam memberikan dorongan kerja kepada pegawai untuk proses penyelesaian pekerjaan. Pimpinan selalu memberikan penjelasan secara detail tentang tugas yang harus diselesiakan dan pimpinan selalu mengendalikan pekerjaan secara ketat dalam upaya untuk melaksanakan tugas atau pekerjaan sesuai dengan ketentuan serta menetapkan batas waktu dalam proses penyelesaian pekerjaan.

Adapun untuk orientasi hubungan menunjukkan bahwa pimpinan menyatakan bahwa selalu menjaga hubungan baik dengan pegawai, dalam memperhatikan keluhan yang disampaikan oleh pegawai, dalam berdiskusi tentang pekerjaan yang harus diselesaikan oleh pegawai, selalu mengkomunikasikan dan mendelegasikan setiap tugas dan tanggung jawab kepada pegawai, dalam berkomunikasi selalu dilakukan dengan baik. Pimpinan dalam menjalanakan aktivitas operasional instansi selama ini selalu melakukan pengendalian dengan memberikan arahan kepada pegawai sehingga pegawai selalu mengikuti sistem dan prosedur secara benar sesuai dengan ketentuan yang telah ditetapkan. Kondisi ini menjadikan sistem komunikasi antara pimpinan dan bawahan selalu dilakukan secara maksimal oleh pimpinan dan pegawai.

Hasil analisis dapat diketahui bahwa terjadi perbedaan gaya kepemimpinan bagian umum dikarenakan selama ini tugas utama dari bagian umum yaitu melakukan koordinasi terhadap tugas-tugas yang harus diselesaikan oleh bagian umum dalam hal ini terkait dengan proses pemeliharaan dan penghapusan barang atau kekayaan milik negara serta melakukan inventalisir barangbarang yang masih layak digunakan untuk mendukung kegiatan operasional instansi. Beberapa tugas tersebut secara langsung dengan pimpinan bagian umum dimana segala bentuk hasil pekerjaan harus mendapat persetujuan dari pimpinan.

Pimpinan berhak memberikan saran dan kritik dengan harapan para pegawai selalu bekerja berdasarkan ketentuan yang telah ditetapkan instansi melalui pimpinan bagian umum. Kondisi ini memperkuat gaya kepemimpinan yang tepat digunakan pada bagian umum adalah konsultatif. Beberapa tugas yang harus diselesaikan tersebut secara langsung membutuhkan gaya kepemimpinan konsultatif, dimana pegawai bagian umum dalam aktivitasnya menyelesaikan tugas-tugasnya dan memutuskan suatu keputusan diperlukan berkonsultasi dengan pimpinan.

Ian Keuangan pada bag Hasil analisis menunjukkan bahwa gaya kepemimpinan pada bagian keuangan 
pada Pengadilan Negeri Situbondo yaitu konsultatif. Sedangkan apabila ditinjau dari kematangan bawahan maka gaya kepemimpinan yang sesuai yaitu parsipatif. Pimpinan bagian keuangan dapat diketahui bahwa selama ini pimpinan menyatakan bahwa pegawai mendukung dalam proses penyelesaian pekerjaan, pegawai memiliki keterampilan dalam menyelesaian pekerjaan yang telah dilakukan, pengalaman kerja yang dimiliki pegawai dalam mendukung kebutuhan kerja, dapat meminimalkan pelanggaran prosedur kerja dan penyelesaian pekerjaan pegawai sesuai dengan target waktu yang telah ditetapkan. Perilaku tugas dapat diketahui bahwa pimpinan menyatakan selalu memberikan instruksi dalam pelaksanaan tugas kepada pegawai.

Frekuensi pimpinan dalam memberikan dorongan kerja kepada pegawai untuk proses penyelesaian pekerjaan. Pimpinan selalu memberikan penjelasan secara detail tentang tugas yang harus diselesiakan dan pimpinan selalu mengendalikan pekerjaan secara ketat dalam upaya untuk melaksanakan tugas atau pekerjaan sesuai dengan ketentuan serta menetapkan batas waktu dalam proses penyelesaian pekerjaan.

Orientasi hubungan menunjukkan bahwa pimpinan menyatakan bahwa selalu menjaga hubungan baik dengan pegawai, dalam memperhatikan keluhan yang disampaikan oleh pegawai, dalam berdiskusi tentang pekerjaan yang harus diselesaikan oleh pegawai, selalu mengkomunikasikan dan mendelegasikan setiap tugas dan tanggung jawab kepada pegawai, dalam berkomunikasi selalu dilakukan dengan baik.

Perbedaan gaya kemimpinan antara pimpinan dengan harapan pegawai dikarenakan selama ini para pegawai mampu tapi tidak mau atau ragu dalam proses penyelesaian pekerjaan. Kondisi ini menjadikan pimpinan selalu mengendalikan aktivitas pegawai dan mendorong untuk bekerja dengan lebih baik diinstansi. Adanya perbedaan tersebut juga disebabkan oleh masa kerja yang dimiliki para pegawai sehingga mereka belum memiliki kemampuan dalam proses penyelesaian pekerjaan. Kondisi ini menjadikan peran pimpinan sebagai pengendali aktivitas pegawai sangat menentukan pencapaian target kerja secara maksimal.

Hasil penelitian ini mendukung penelitian yang dilakukan oleh Ana Elok Imtihanah (2009), yang diperoleh hasil bahwa kepemimpinan yang mengedepankan hubungan yang baik dan keteladanan yang tinggi dan tugas yang sangat maksimal dan optimal, menunjukkan bahwa peran pimpinan sebagai pengendali aktivitas operasional karyawan sangat dibutuhkan. Hasil penelitian juga didukung oleh teori yang dikemukakan oleh Thoha (2004:315) kematangan (maturity) dalam situasional dapat dirumuskan sebagai suatu kemampuan orangorang yang mau bertanggung jawab dalam mengarahkan perilakunya sendiri.

Kemampuan yang merupakan salah satu unsur dalam kematangan, berkaitan dengan pengetahuan atau ketrampilan yang dapat diperoleh dan pendidikan, latihan atau pengalaman. Adapun kemauan merupakan unsur 
yang lain dari kematangan bertalian dengan keyakinan diri dan motivasi seseorang.

Terjadinya perbedaan gaya kepemimpinan pada bagian tersebut terkait dengan tugas yang harus diselesaikan oleh bagian keuangan yaitu mengenai pertanggung jawaban seluruh aktivitas yang keuangan instansi. Tugas lain yang harus dilakukan bagian keuangan juga terkait dengan proses pemeriksaan secara rinci terkait dengan keuangan instansi. Selain itu bagian keuangan juga melakukan kesesuaian antara rencana kerja dengan kelayakan yang harus dicapai sesuai dengan ketentuan yang telah ditetapkan instansi serta melakukan pemeriksaan kebenaran atas tagihan dan melaksanakan anggaran kerja bagian keuangan sesuai prosedur yang telah ditetapkan.

Beberapa tugas tersebut mengindikasikan bahwa gaya kepemimpinan yang sesuai untuk bagian keuangan yaitu konsultatif, dimana keberadaan pimpinan untuk memberikan arahan dapat memberikan dukungan dalam proses penyelesaian pekerjaan.

\section{SIMPULAN}

Berdasarkan hasil penelitian maka dapat diketahui bahwa tingkat kematangan bawahan di Pengadilan Negeri Situbondo dapat diuraikan bahwa untuk bagaian kepegawai masuk dalam kategori tinggi, bagian umum sangat tinggi dan bagian keuangan masuk dalam kriteria tinggi. Gaya kepemimpinan perilaku tugas dan perilaku hubungan di Pengadilan Negeri Situbondo dapat diuraikan sebagai berikut untuk perilaku tugas pada bagian kepegawai masuk dalam kategori tinggi, bagian umum tinggi dan bagian keuangan masuk dalam kriteria tinggi. Perilaku hubungan pada bagian kepegawai masuk dalam kategori sangat tinggi, bagian umum tinggi dan bagian keuangan masuk dalam kriteria tinggi. Gaya kepemimpinan yang sesuai dengan teori Hersey dan Blanchard di Pengadilan Negeri Situbondo yaitu konsultatif.

Saran dalam penilitan ini adalah pimpinan bagian kepegawaian, umum dan keuangan diharapkan untuk menerapkan gaya kepemimpinan konsultatif. Upaya yang dapat dilakukan pimpinan yaitu harus lebih aktif dalam mengendalikan aktivitas yang dilakukan oleh pegawai dengan memberikan masukan-masukan serta arahan agar pegawai dapat menjalankan aktivitas operasional instansi sesuai dengan ketentuan yang telah ditetapkan.

Pimpinan harus menetapkan batas waktu dalam proses penyelesaian pekerjaan sehingga pekerjaan dapat selesai tepat pada waktunya sehingga arahan yang diberikan benar-benar dijalankan sesuai dengan harapan. Pimpinan harus memberikan dorongan atau motivasi kepada pegawai agar menyelesaikan pekerjaan yang menjadi tanggung jawab sesuai dengan ketentuan yang ditetapkan. Bentuk tanggung jawab dilakukan dengan memberikan metode secara tepat sehingga pegawai mudah memahami atas perintah atau arahan dari pimpinan.

\section{DAFTAR PUSTAKA}

Ana Elok Imtihanah, 2009, Analisis Gaya Kepemimpinan Dalam Meningkatkan Kinerja Pegawai 
Pada Fakultas Ekonomi Universitas Islam Negeri Maulana Malik Ibrahim Malang, Skripsi Universitas Islam Negeri Maulana Malik Ibrahim Malang

Arifin, Amirullah, Fauziah, 2005, Perilaku Organisasi, Edisi 1, Penerbit Bayumedia, Malang.

As'ad, Muhammad. 2004. Psikologi Industri : seri Ilmu Sumber Daya Manusia. Edisi keempat, Yogyakarta : Gajah Mada University Press.

Luthans, 2006, Manajemen Personalia Dan Sumber Daya Manusia, Edisi 2, Cetakan Ketujuh, BPFE, Yogyakarta.

Thoha, Miftah, 2004, Perilaku Organisasi, Konsep Dasar dan Aplikasinya, Rajawali Jakarta.

Mohyi, Ahmad, 2005, Teori dan Perilaku Organisasi, Malang: CV. Cahaya Press.
M. Ali Iqbal, 2010, Analisis Gaya Kepemimpinan Path goal Terhadap Efektivitas Organisasi Pada Badan Penelitian Dan Pengembangan Pertanian, Departemen Pertanian, Skripsi Universitas Esa Unggul, Jakarta.

Mangkunegara, Anwar Prabu, 2006, Manajemen Sumber Daya Manusia Perusahaan, Cetakan Kedua, PT. Remaja Rosdakarya Offset, Bandung.

2007,

Manajemen Sumber Daya Manusia Perusahaan, Cetakan Kedua, PT. Remaja Rosdakarya Offset, Bandung.

Sugiyono. 2006. Metode Penelitian Kuantitatif Kualitatif dan R\&D. Alfabeta, Bandung 